\title{
MIR194-1 wt Allele
}

National Cancer Institute

\section{Source}

National Cancer Institute. MIR194-1 wt Allele. NCI Thesaurus. Code C95035.

Human MIR194-1 wild-type allele is located in the vicinity of 1q41 and is 85 bases in length. This allele, which encodes MIR194-1 pre-miRNA, may play a role in the regulation of transcription. Aberrant expression of the gene is associated with multiple myeloma. 